\title{
Optimization of perforated liner parameters in horizontal oil wells
}

\author{
Milad Ebrahimi Dastgerdi ${ }^{1} \cdot$ Abbas Khaksar Manshad $^{2} \cdot$ Amir H. Mohammadi $^{1}$ []
}

Received: 10 April 2020 / Accepted: 30 June 2020 / Published online: 11 September 2020

(c) The Author(s) 2020

\begin{abstract}
Nowadays, horizontal wells play a vital role in the production from thin heavy oil reservoirs. Designing a suitable completion for this kind of reservoirs is a decisive factor to boost the efficiency of durable production. This study deals with the optimization of perforated liner design for horizontal wells in Sarvak oil reservoir, which is located in the southwest of Iran. Sarvak is a carbonate oil reservoir, but it contains shale and mudstone. To avoid solid production and formation collapse, the screen liner was selected as a cost-effective solution. There were two choices, either perforated liner or slotted liner. The perforated liner was selected by finite element analysis and strength checking, which was proven by laboratory experiments. Sensitivity analysis was performed on various perforated parameters such as phase angle, hole density, hole diameter and hole distribution to determine the pattern of the holes so that enough strength of the liner was maintained while maintaining the maximum hole density. Then, parameters of perforated liner were determined by calculated loss of the flowing path, collapse resistance strength and tensile strength of casing pipes after perforated. As a result, hole density, hole size and perforated pattern were selected $100 \mathrm{HPM}, 10 \mathrm{~mm}$ and 4-thread-line, respectively, in $4 \frac{1}{2} 2$ " liner with $13.5 \mathrm{ppf}$. The ratio of the strength of the optimized perforated liner was less than $8 \%$ for collapse and $5 \%$ for tensile compared to the same specification casing.
\end{abstract}

Keywords Perforated liner $\cdot$ Slotted liner $\cdot$ Screen liner $\cdot$ Collapse analysis $\cdot$ Horizontal well $\cdot$ Optimization

\section{Introduction}

Due to the strategic role of horizontal wells in the production from oil reservoirs, as well as significant advances in drilling technology and well completion, the use of these wells has increased more than before and choosing the method of economic completion with the right efficiency is an art. An efficient well completion method must be done, while maintaining the mechanical integrity of the borehole, without creating significant restrictions on production capacity, and it has to be economical (Furui et al. 2004). Choosing the right method for completion in horizontal wells in thin

Abbas Khaksar Manshad

khaksar@put.ac.ir

$\bowtie$ Amir H. Mohammadi amir_h_mohammadi@yahoo.com

1 Discipline of Chemical Engineering, School of Engineering, University of KwaZulu-Natal, Howard College Campus, King George V Avenue, Durban 4041, South Africa

2 Department of Petroleum Engineering, Abadan Faculty of Petroleum Engineering, Petroleum University of Technology (PUT), Abadan, Iran heavy oil reservoirs plays a vital role. Therefore, optimizing the completion in horizontal wells is of great importance.

In designing the completion of horizontal wells in each field, in addition to the characteristics of the rock and fluid of the reservoir, economic considerations, etc., special attention should be paid to problems such as wellbore stability, solid/sand production and so on. The need to examine various aspects of optimizing the completion of horizontal wells complicates this task.

The field studied in this work is located in the southwest of Iran. It is currently the largest developing oil field in the world (Liu et al. 2013). This field has several reservoirs, but the most percentage of production rate comes from the Sarvak oil reservoir. Sarvak as a target reservoir has $4 \mathrm{~m}$ thickness, and it consists of a heavy oil of $19.95^{\circ}$ API, 4.44-5.44 cP. viscosity and 276-441 SCF/STB GOR (Manshad et al. 2019). The reservoir drive mechanism is rock and liquid expansion and formation is homogeneous. In this reservoir, the wells are drilled with 800 meters of horizontal section. The open hole has been adapted for this field as a common completion in the horizontal section. However, this method does not have the required efficiency and after a 
relatively short period of production time, the rate of production has been reduced.

Sarvak is a carbonate reservoir, but it contains shale and mudstone; it may be stable in the initial phase of exploitation but the borehole wall will become unstable after acidizing or in the later phase of production. The research shows that the acid will reduce the mechanical strength of rocks (Gou et al. 2019). After a short time of production, discharging large debris of shale has significantly affected production rate. They settled in the horizontal section and cause a decline in productivity of the well.

In the case of completion method selection, having a balance between well productivity, intervention activities and cost economics is a key point (Kumar et al. 2010; Liu and Morita 2018). Accordingly, choosing a perforated or slotted liner is likely an appropriate and cost-effective completion method in this oil field. Screen liners are widely used to improve the performance of horizontal wells in sandstone (Furui et al. 2012), limestone (Zaisheng et al. 2001) and also shale reservoirs (Liu and Morita 2018). There are massive studies on the perforated and slotted liner (see Table 1).

\section{Application of perforated and slotted liner}

There are general purposes for using of the perforated liner; low cost and prevention hole collapse by formation over time (Abbassian and Parfitt 1998). This method is one of the most cost-effective solid/sand control methods (Ahsan and Etesami 2013).

\section{Perforated and slotted liner design considerations}

Following items have been considered:

A. Maximum hole density and hole diameter from the point of inflow/outflow and stimulation with considering the hole size based on the size of produced solids and also hole density based on the flow path open area.

B. The screen liner must be able to withstand loads of installation because holes reduce the mechanical capacity of the production string (Jorden et al. 2011).

C. The strength of pre-drilled liner cannot be less than $80 \%$ of the same specification casing (Mantovano and Grittini 2016).

D. The total block of holes per joint should exceed the ID cross-sectional block of the major production string but should not exceed $3 \%$ of the total surface block of the joint to be drilled. By increasing the open area to more than 3\%, the collapse strength and rotational capacity of a screen liner are reduced significantly. Besides, an open area above 5\% strongly affects the collapse strength and torsional capacity of the liner (Kumar et al. 2010).

\section{Methodology of the study}

Figure 1 shows the algorithm for optimizing perforated liner parameters in horizontal wells. According to an analysis of offset wells PVT data, the reservoir pressure and temperature

Table 1 Review of previous studies on perforated/slotted liner

\begin{tabular}{|c|c|c|}
\hline Refererences & Method & Study on \\
\hline Abbassian and Parfitt (1998) & $\begin{array}{l}\text { Modeling (based on elastic ovalization and subsequent } \\
\text { plastic collapse by formation) }\end{array}$ & $\begin{array}{l}\text { Evaluating the collapse strength and post-collapse } \\
\text { behavior of oil field tubulars subjected to external } \\
\text { pressure }\end{array}$ \\
\hline Santos et al. (2008) & $\begin{array}{l}\text { Modeling (Contact between granular materials and } \\
\text { soil-pipe interaction) }\end{array}$ & Collapse analysis of screens \\
\hline Fuh et al. (2009) & Numerical model & Sand-screen collapse resistance under geotectonic load \\
\hline Kumar et al. (2010) & Engineering design & $\begin{array}{l}\text { Optimization of slot size and geometry that minimizes } \\
\text { slot plugging and near wellbore flow convergence } \\
\text { losses. }\end{array}$ \\
\hline Jorden et al. (2011) & Finite element analysis & Pre-perforated Liner Design \\
\hline Xie (2015) & Finite element analysis (FEA) modeling & Slotted liner design for sand control in SAGD wells \\
\hline Mantovano and Grittini (2016) & Modeling & Structural resistance of pre-perforated liners \\
\hline Beltrán and Netto (2017) & Numerical, analytical and experimental studies & Collapse analysis of perforated pipes \\
\hline Naizhen and Qing-chun (2018) & $\begin{array}{l}\text { Subsection optimization model (based on the slotted } \\
\text { screen completion skin model and the horizontal } \\
\text { wellbore inflow control principle) }\end{array}$ & Skin factor model of slotted screen liner \\
\hline Liu and Morita (2018) & 3D finite element analysis and experimental study & Collapse and bending analysis of slotted liners \\
\hline
\end{tabular}




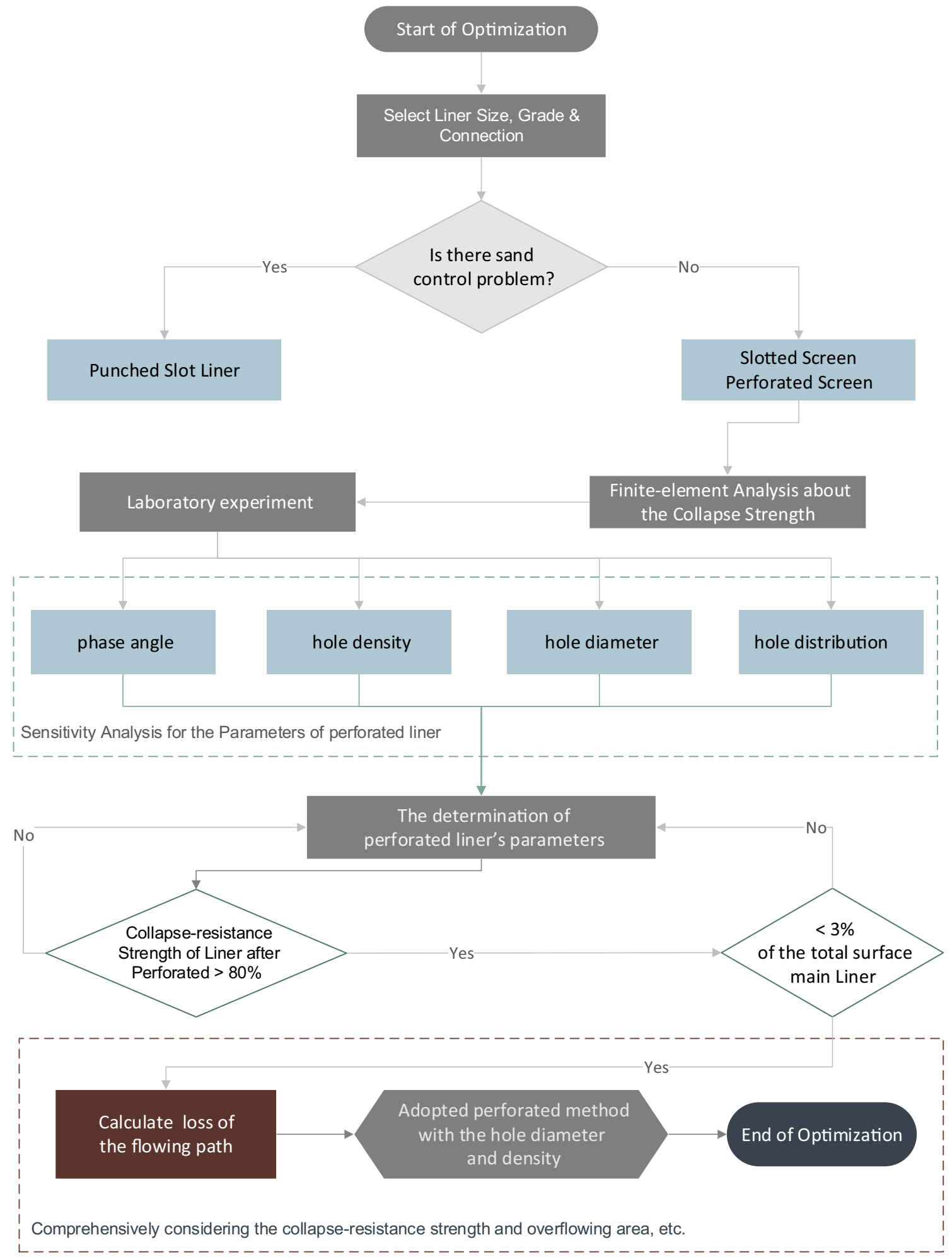

Fig. 1 Flowchart for screen liner optimization 

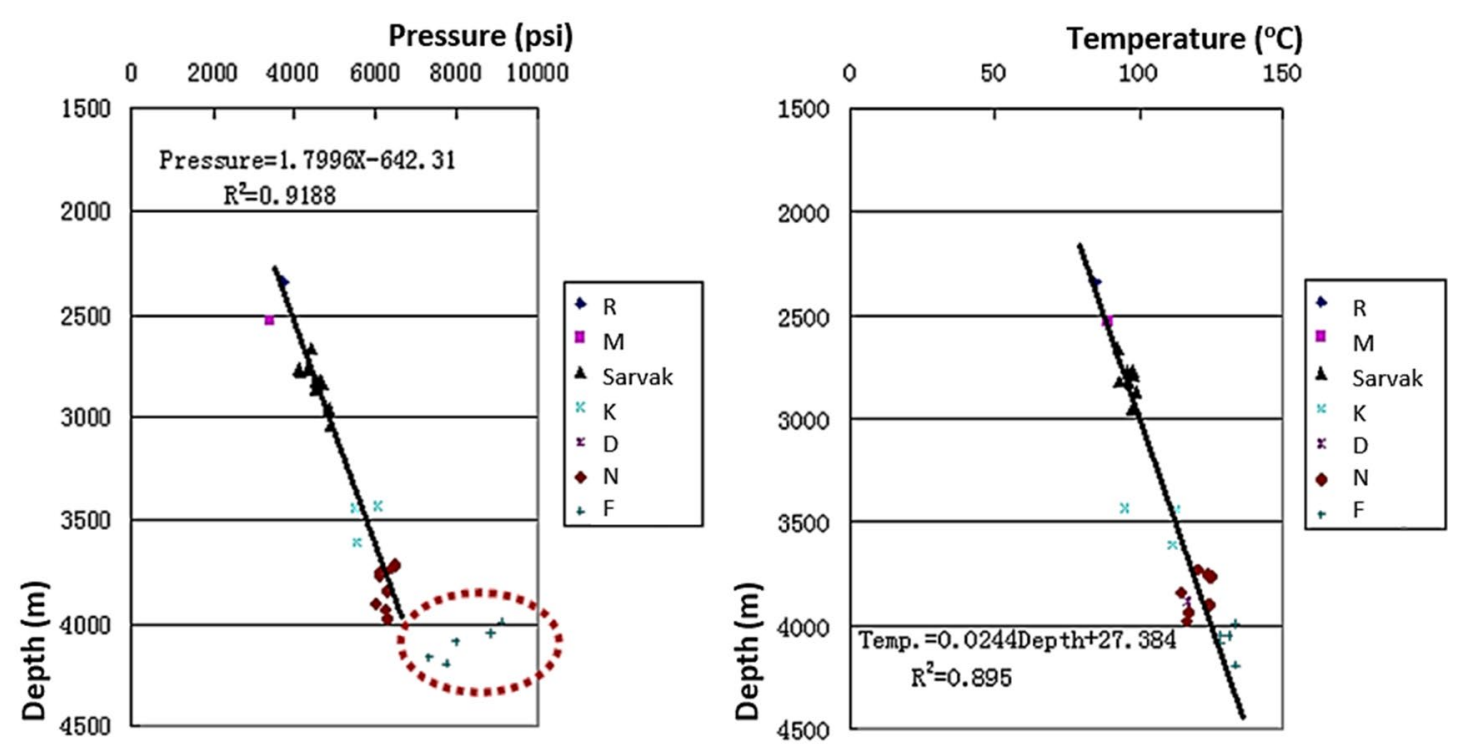

Fig. 2 Tested pressure (left) and tested temperature (right) in offset wells

Table 2 Sarvak reservoir information

\begin{tabular}{ll}
\hline Formation & Sarvak \\
\hline Reservoir depth $(\mathrm{m})$ & $2709-2850$ \\
Pressure (Psi) & $4600-5029$ \\
Press. coeff. & $1.14-1.26$ \\
Temperature $\left({ }^{\circ} \mathrm{C}\right)$ & 96 \\
Temp. grad $\left({ }^{\circ} \mathrm{C} / 100 \mathrm{~m}\right)$ & $2.4-2.6$ \\
Lithology & Carbonate \\
\hline
\end{tabular}

Table 3 Minimum design factors

are shown in Fig. 2 and Table 2. The formation pore pressure coefficient (FPPC) is 1.02-1.26 in Sarvak.

The blind liner 4-1/2"/L-80/13.5 PPF was designed according to the IPS (Iranian Petroleum Standards), SY/T 5431-2008 and American Petroleum Institute (API). The stress analysis was conducted by using conventional working stress design procedures, where stresses due to various load conditions were calculated and compared to the API minimum yield strength of the tubular. Table 3 illustrates the safety design criteria used in this study. Also, Fig. 3 shows the stress check for $41 / 2^{\prime \prime}$ liner.

\section{Selection of the type of screen liner}

The commonly used screens are mainly divided into the perforated screen, slotted screen and punched slot liner. Two principles of screen selection must be followed: One is to ensure enough strength, and the other is the flow block that must meet the requirement of the production. As mentioned earlier, Savark is a carbonate reservoir. The wellbore is relatively stable, and the problem of sand production is not necessary to be considered. The function of the screen is to prevent formation collapses and to prevent the large debris from discharging with fluids. Therefore, we will select either perforated screen or slotted screen liner.

Casing collapse resistance strength was used to measure the capability of the casing to instability and failure (Lou et al. 2011). Therefore, finite element analysis (FEA) was run as a computerized method for predicting the collapse strength of the slotted and perforated liner with the same flow block. The results are shown in Fig. 4. The collapse strength of the slotted screen is much lower than the perforated screen, which has been proven by laboratory experiments (Figs. 5 and 6).

Perforating screen pipes are formed by direct punching on the base pipes and will not be influenced by heat stress. They can ensure the effective overflowing block of fluids, and at the same time, reserve a relatively high strength for the largest pipe. Their tripping-in is easy in long horizontal sections. In slotted screen, the heat stress of the slotted screen pipes cannot be eliminated, the brittleness of the slotted screen pipes increases and the resistance to corrosion reduces. The maximum effective overflowing block and pipe strength cannot be ensured, the collapse resistance strength is limited, 


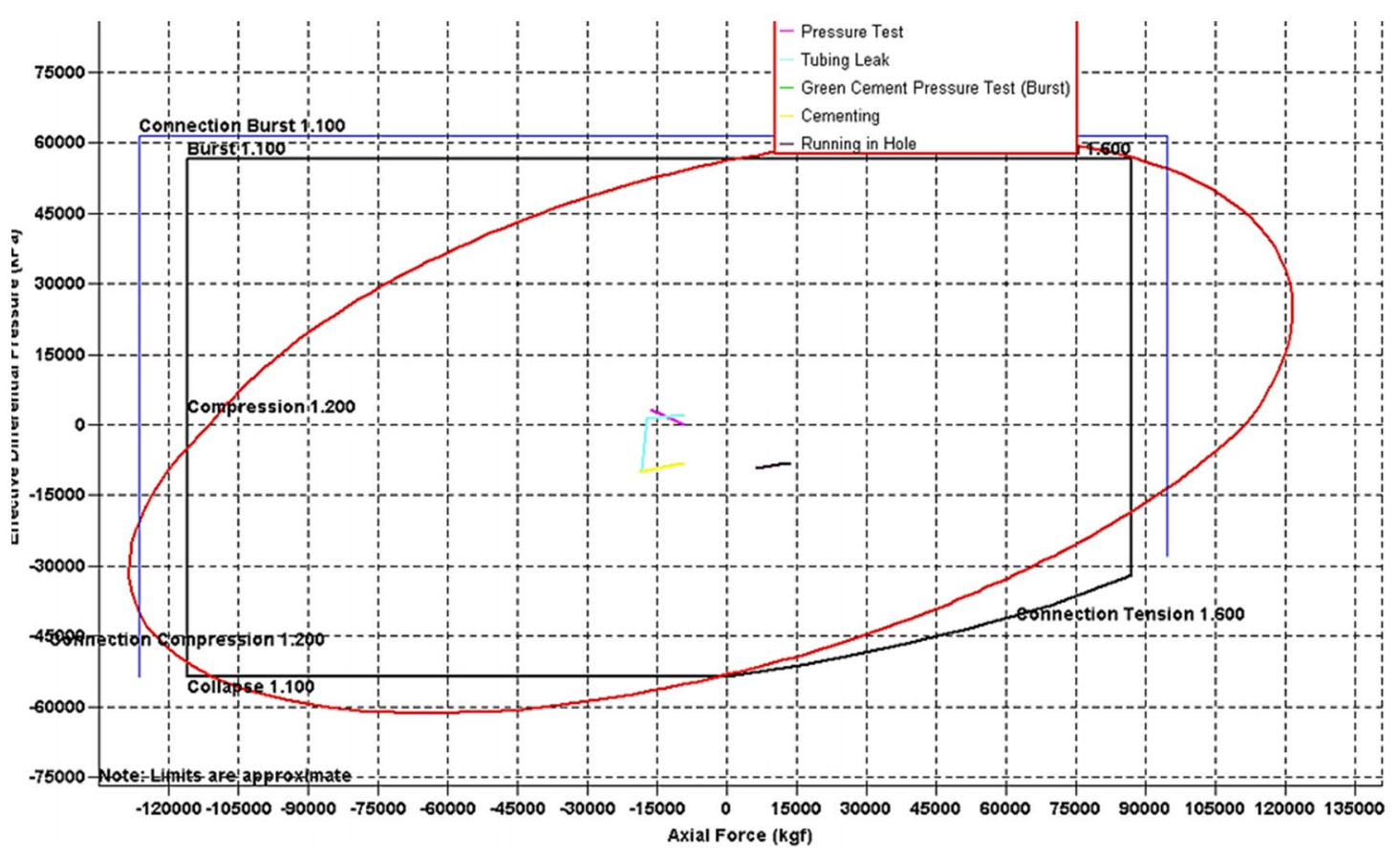

Fig. 3 Stress check for 4 1/2" liner
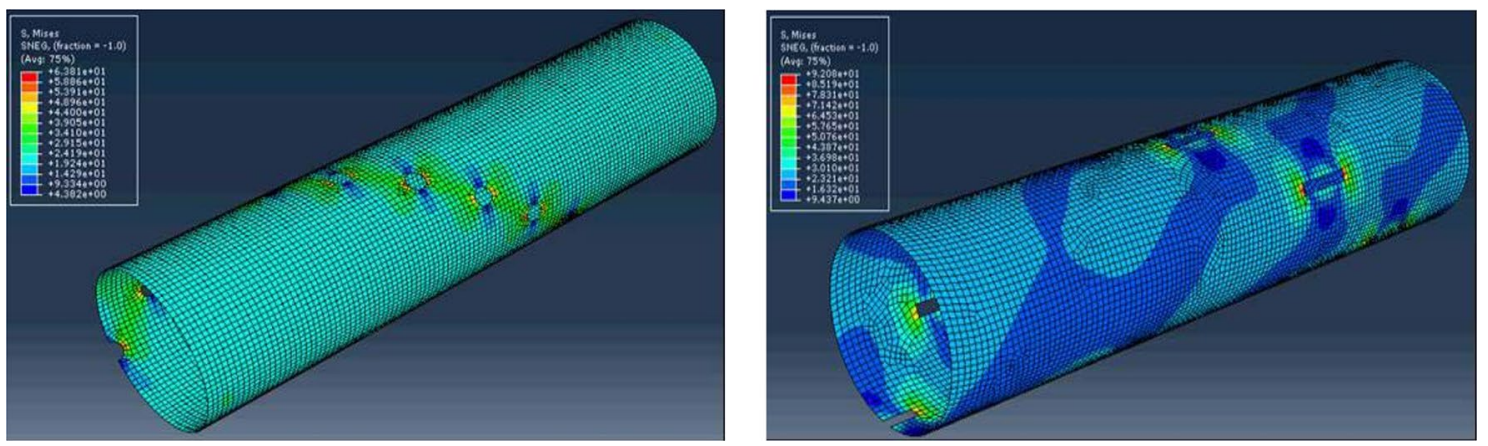

Fig. 4 Finite element analysis results of the collapse strength of slotted screen and perforated screen
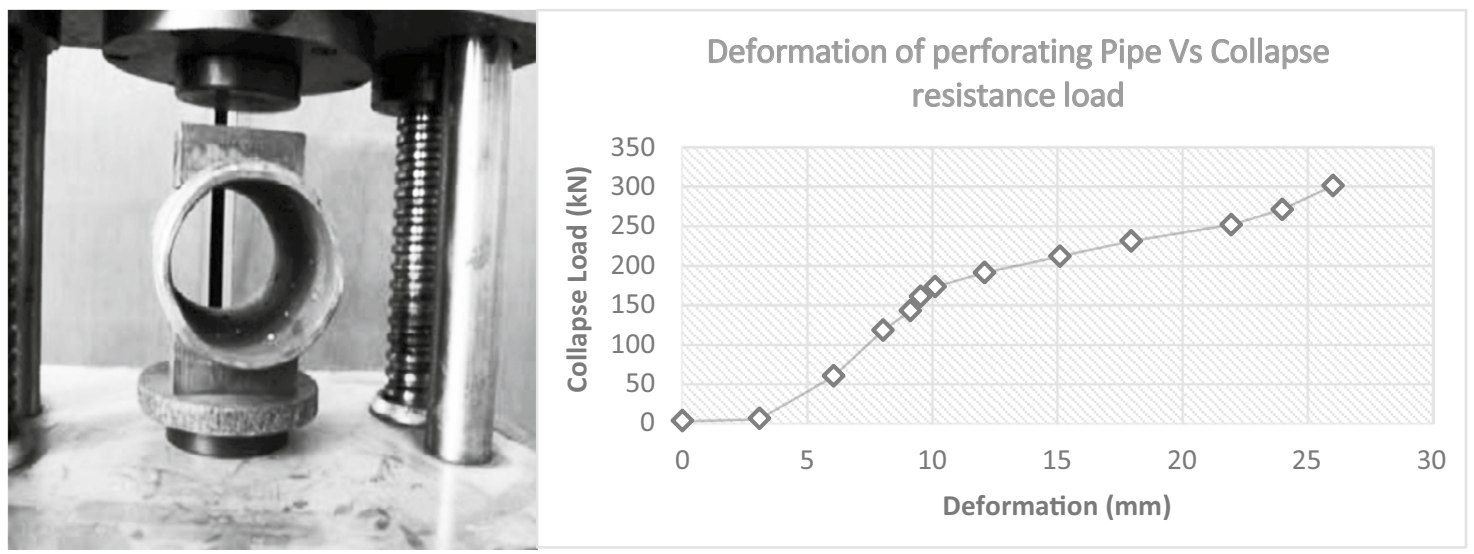

Fig. 5 Collapse resistance load of perforated liner 

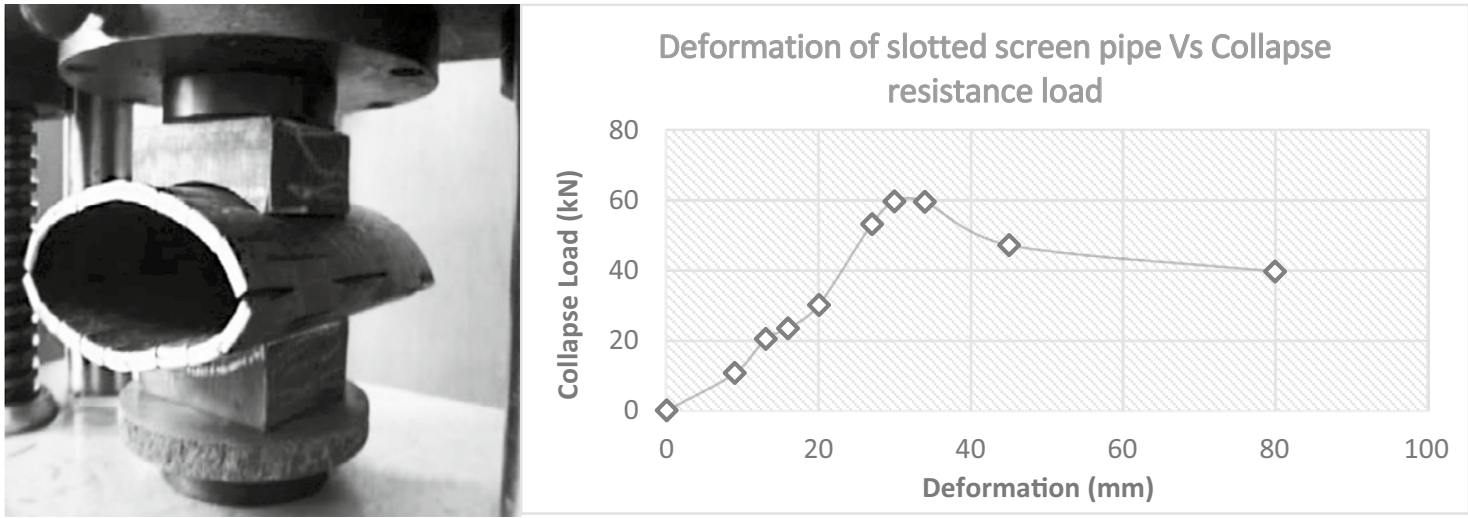

Fig. 6 Collapse resistance load of slotted screen

and deformation is easy to be generated during running in long horizontal sections. Tripping-in is not suitable in long horizontal sections.

\section{Sensitivity analysis for the parameters of perforated liner}

Sensitivity analysis was performed on various phase angles, hole densities, hole diameters and hole distributions to determine the pattern of the holes so that the enough strength of the liner is maintained while maintaining the maximum hole density (see Figs. 7, 8, 9, and 10). than the influence of hole density on collapse resistance strength at different phases. The sensitivity of hole diameter and hole density on collapse resistance strength are relatively the lowest at the $45^{\circ}$ phase.

\section{Determination of parameters of perforated liner}

\section{The calculation of collapse resistance strength}

The decrease extent of the collapse resistance strength of casing pipes after perforated on casing pipes is calculated as per the following equation:

$\alpha=\frac{(K-1) \sigma_{\max }}{\sigma_{S}}=\frac{(0.0282+0.0024 d+0.0011 q+0.0002 w) P_{i}(1+\mu) \sqrt{R_{i}^{4}+3 R_{0}^{4}}}{\left[R_{i}^{2}+R_{0}^{2}+\mu\left(R_{i}^{2}-R_{0}^{2}\right)\right] \sigma_{s}}$

It is shown from the above figures that the influence of hole diameter on collapse resistance strength is far greater where $P_{i}$ is the internal pressure of the casing pipe in MPa. The bubble pressure is $2000 \mathrm{psi}$, which is taken as the internal
Fig. 7 Influence of hole diameter on collapse resistance strength at different phases

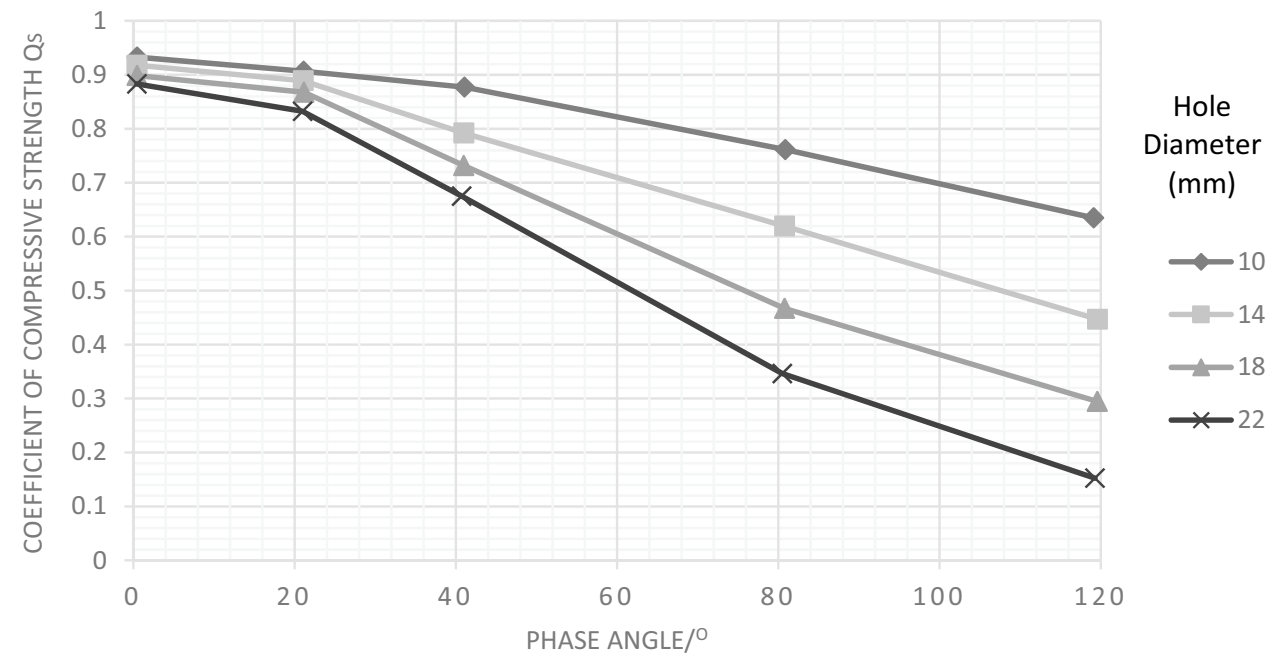


Fig. 8 Influence of hole density on collapse resistance strength at different phases

Fig. 9 Influence of different hole densities and hole diameters on collapse resistance strength factor

Fig. 10 Influence of different numbers of perforated lines on collapse resistance strength
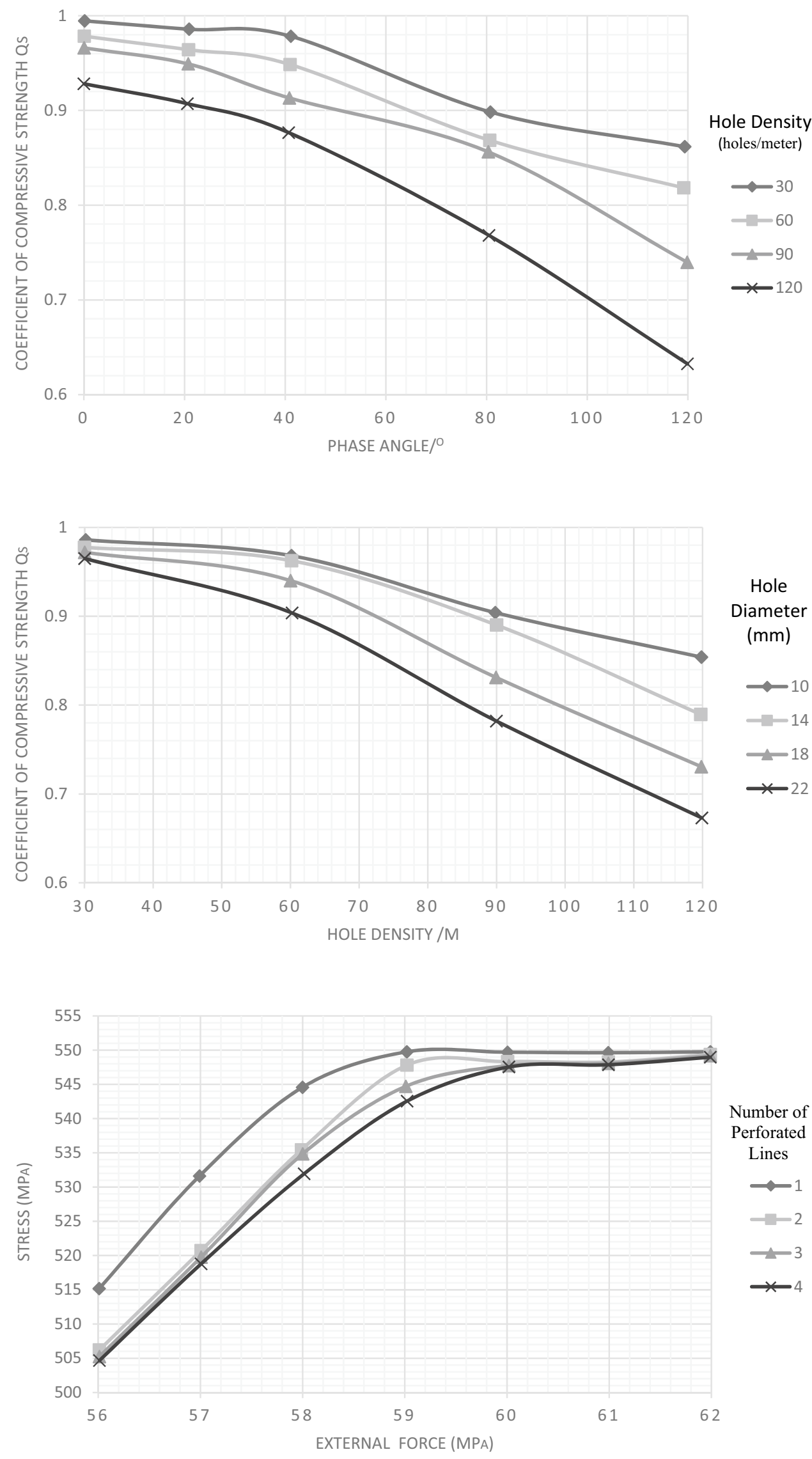
pressure of casing pipe, or $13.78 \mathrm{MPa} . R_{i}$ : inner diameter of casing pipe $(100.6 \mathrm{~mm})$; Ro: outer diameter of casing pipe (114.3 mm); M: Poisson's ratio of steel (0.25-0.3, taking 0.3); $\sigma_{s}$ : Yield limit (9210 psi, taking $63.47 \mathrm{MPa}$ ); $d$ : hole diameter $(\mathrm{mm}) ; q$ : hole density (holes $/ \mathrm{m}) ; w$ : phase of $\operatorname{shot}\left({ }^{\circ}\right)$.

It can be seen from Table 4 that the decrease extent of the collapse resistance strength of the casing pipes after perforation is limited.

\section{Calculation of tensile strength}

The tensile strength after perforated in the base pipe changing is calculated as follows:

$P_{P}=P \times \frac{P \times S}{P \times S_{0}}$

where $P_{p}$ : the tensile strength after perforated; $P$ : minimum tensile strength before perforated; $S$ : the cross-section area of the base pipe after perforated; $S_{0}$ : the cross-sectional area of the base pipe before perforated.

Between 8 and $12 \mathrm{~mm}$ hole diameter, every meter 280 holes, the perforated screen before and after drilling tensile strength was all above $80 \%$ and met the requirements
Table 5 Tensile strength of casing after perforated

\begin{tabular}{lll}
\hline $\begin{array}{l}\text { Hole diameter } \\
(\mathrm{mm})\end{array}$ & $\begin{array}{l}\text { Hole density (hole/ } \\
\text { meter })\end{array}$ & $\begin{array}{l}\text { Before and after drilling } \\
\text { tensile strength ratio }(\%)\end{array}$ \\
\hline 8 & 280 & 95.73 \\
10 & 280 & 93.32 \\
12 & 280 & 91.66 \\
\hline
\end{tabular}

of the tensile strength (Table 5). The influence of the hole diameter changing on the tensile strength is very small and thus can be ignored.

\section{Calculation of holes per meter}

To calculate the required percentage of the open area on the pipe surface, the diameter of the desired hole must first be selected. Then, the number of holes per foot of the pipe is achieved using the following equation (see the result in Table 6):

$N=\frac{(12 \times D \times C)}{\left(25 \times d^{2}\right)}$

Table 4 Collapse resistance strength of casing after perforated

\begin{tabular}{|c|c|c|c|c|c|c|c|c|}
\hline $\begin{array}{l}\text { Internal pres- } \\
\text { sure (MPa) }\end{array}$ & $\begin{array}{l}\text { Inner diam- } \\
\text { eter }(\mathrm{mm})\end{array}$ & $\begin{array}{l}\text { Outer diam- } \\
\text { eter }(\mathrm{mm})\end{array}$ & Poisson's ratio & $\begin{array}{l}\text { Yield limit } \\
\text { (MPa) }\end{array}$ & $\begin{array}{l}\text { Hole diameter } \\
(\mathrm{mm})\end{array}$ & $\begin{array}{l}\text { Hole density } \\
\text { (shots } / \mathrm{m})\end{array}$ & Phase $\left(^{\circ}\right)$ & $\begin{array}{l}\text { Strength } \\
\text { decrease (\%) }\end{array}$ \\
\hline 13.78 & 100.6 & 114.3 & 0.3 & 63.47 & 6 & 120 & 45 & 5.76 \\
\hline 13.78 & 100.6 & 114.3 & 0.3 & 63.47 & 6 & 140 & 45 & 6.45 \\
\hline 13.78 & 100.6 & 114.3 & 0.3 & 63.47 & 6 & 160 & 45 & 7.14 \\
\hline 13.78 & 100.6 & 114.3 & 0.3 & 63.47 & 6 & 180 & 45 & 7.83 \\
\hline 13.78 & 100.6 & 114.3 & 0.3 & 63.47 & 6 & 200 & 45 & 8.52 \\
\hline 13.78 & 100.6 & 114.3 & 0.3 & 63.47 & 6 & 220 & 45 & 9.21 \\
\hline 13.78 & 100.6 & 114.3 & 0.3 & 63.47 & 8 & 120 & 45 & 5.91 \\
\hline 13.78 & 100.6 & 114.3 & 0.3 & 63.47 & 8 & 140 & 45 & 6.60 \\
\hline 13.78 & 100.6 & 114.3 & 0.3 & 63.47 & 8 & 160 & 45 & 7.29 \\
\hline 13.78 & 100.6 & 114.3 & 0.3 & 63.47 & 8 & 180 & 45 & 7.98 \\
\hline 13.78 & 100.6 & 114.3 & 0.3 & 63.47 & 8 & 200 & 45 & 8.67 \\
\hline 13.78 & 100.6 & 114.3 & 0.3 & 63.47 & 8 & 220 & 45 & 9.36 \\
\hline 13.78 & 100.6 & 114.3 & 0.3 & 63.47 & 10 & 120 & 45 & 6.06 \\
\hline 13.78 & 100.6 & 114.3 & 0.3 & 63.47 & 10 & 140 & 45 & 6.75 \\
\hline 13.78 & 100.6 & 114.3 & 0.3 & 63.47 & 10 & 160 & 45 & 7.44 \\
\hline 13.78 & 100.6 & 114.3 & 0.3 & 63.47 & 10 & 180 & 45 & 8.13 \\
\hline 13.78 & 100.6 & 114.3 & 0.3 & 63.47 & 10 & 200 & 45 & 8.82 \\
\hline 13.78 & 100.6 & 114.3 & 0.3 & 63.47 & 10 & 220 & 45 & 9.51 \\
\hline 13.78 & 100.6 & 114.3 & 0.3 & 63.47 & 12 & 120 & 45 & 6.21 \\
\hline 13.78 & 100.6 & 114.3 & 0.3 & 63.47 & 12 & 140 & 45 & 6.9 \\
\hline 13.78 & 100.6 & 114.3 & 0.3 & 63.47 & 12 & 160 & 45 & 7.59 \\
\hline 13.78 & 100.6 & 114.3 & 0.3 & 63.47 & 12 & 180 & 45 & 8.28 \\
\hline 13.78 & 100.6 & 114.3 & 0.3 & 63.47 & 12 & 200 & 45 & 8.97 \\
\hline 13.78 & 100.6 & 114.3 & 0.3 & 63.47 & 12 & 220 & 45 & 9.66 \\
\hline
\end{tabular}


Table 6 Determining holes per meter

\begin{tabular}{lll}
\hline $\begin{array}{l}\text { Hole diameter } \\
(\mathrm{mm})\end{array}$ & $\begin{array}{l}\text { Hole density (holes/ } \\
\text { meter })\end{array}$ & $\begin{array}{l}\text { Percentage of open area } \\
\text { on the pipe surface }(\%)\end{array}$ \\
\hline 8 & 196 & 3 \\
10 & 120 & 3 \\
12 & 87 & 3 \\
\hline
\end{tabular}

where $N=$ required holes/foot, $D=$ outside diameter of liner (in), $C=$ required open area (percent of surface area), $d=$ diameter of hole (in).

\section{Calculation of loss of the flowing path}

The loss of the flowing path when the crude oil flowing through the base pipe is calculated as follows:

$$
\Delta P_{R}=\frac{\xi P \mu^{2}}{2}=\frac{\xi O P D^{2}}{2070 p d^{4}}
$$

Assuming that the daily oil production is $3000 \mathrm{bpd}$, the relative density of the crude oil is 0.90 , and the local resistance factor is 0.95 according to the submerged flow (see Figs. 11, 12).

It can be seen that when crude oil flows through the small holes on the base pipes, the influence of the flow path loss on the flowing of crude oil in well holes is very small and thus can be ignored.

Comprehensively considering the collapse resistance strength and overflowing area, 4-connection-line perforated method is adopted with the hole diameter of $10 \mathrm{~mm}$ and hole density of 100-120 holes/m (Table 7).

\section{Conclusion}

The design must be effective in solving the specific problems of a field. The proposed design for the Sarvak oil reservoir specifically addresses the problems of formation collapses

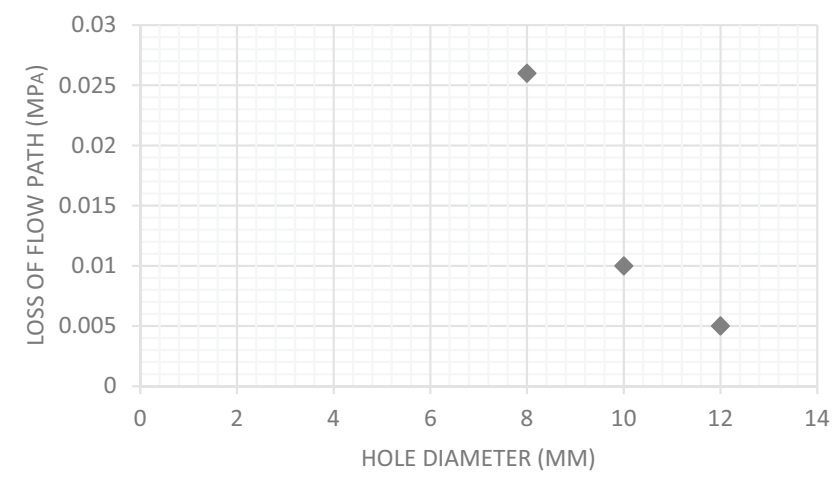

Fig. 12 Hole diameter Vs. the loss of flow path

Table 7 Optimum perforated liner specification for horizontal well

\begin{tabular}{lll}
\hline No. & Item & Technical index \\
\hline 1 & Size & $4-1 / 2^{\prime \prime}$ \\
2 & Weight & $13.5 \mathrm{ppf}$ \\
3 & Perforated Pattern & 4 -thread-line \\
4 & Hole Size & $10 \mathrm{~mm}$ \\
5 & Shot density & 100 holes per meter \\
6 & Connection & BTC \\
\hline
\end{tabular}

and controlling large debris from discharging with fluids. Due to the problems mentioned and also the 800-meter length of the horizontal section, two options, slotted liner and perforated liner, were selected as the best options economically and technically. In the next step, both options were analyzed by the FEA method. The FEA results show that the collapse strength of the slotted liner is much lower than the perforated liner, which has been proven by laboratory experiments. After selecting perforated liner, a sensitive analysis was performed on it. The sensitivity analysis has shown that the influence of hole diameter on collapse resistance strength is far greater than the influence of hole density on collapse resistance strength at different phases. The optimum designed perforated liner has a ratio of strength
Fig. 11 Cross-sectional area of base pipe before and after perforated
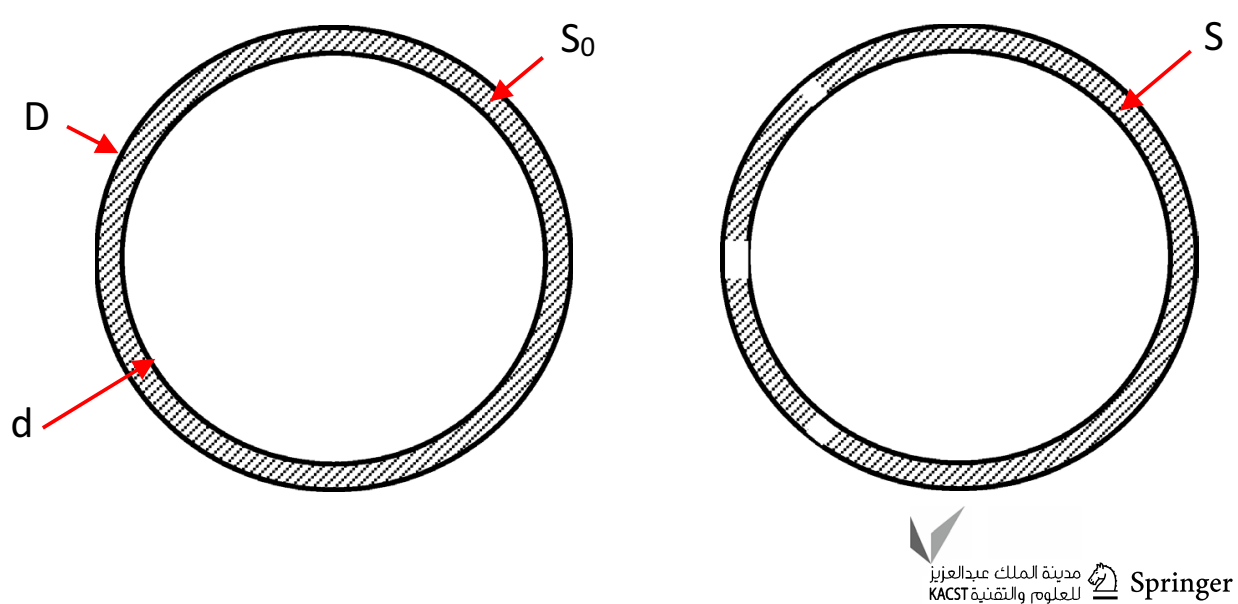
less than $8 \%$ for collapse and $5 \%$ for tensile compared to the same specification casing.

Open Access This article is licensed under a Creative Commons Attribution 4.0 International License, which permits use, sharing, adaptation, distribution and reproduction in any medium or format, as long as you give appropriate credit to the original author(s) and the source, provide a link to the Creative Commons licence, and indicate if changes were made. The images or other third party material in this article are included in the article's Creative Commons licence, unless indicated otherwise in a credit line to the material. If material is not included in the article's Creative Commons licence and your intended use is not permitted by statutory regulation or exceeds the permitted use, you will need to obtain permission directly from the copyright holder. To view a copy of this licence, visit http://creativecommons.org/licenses/by/4.0/.

\section{References}

Abbassian F, Parfitt SHL (1998) A simple model for collapse and postcollapse behavior of tubulars with application to perforated and slotted liners. SPE Drill Complet 13(03):190-196

Ahsan D, Etesami S (2013) The optimization of a slotted liner design for a horizontal well. Pet Sci Technol 31(21):2178-2190

Beltrán K, Netto T (2017) Collapse analysis of perforated pipes under external pressure. In: SPE Latin America and caribbean mature fields symposium, Salvador, Bahia, Brazil

Fuh GF, Morita N, Furui K (2009) Modeling analysis of sand-screen collapse resistance under geotectonic load. In: SPE annual technical conference and exhibition, New Orleans, LA

Furui K, Zhu D, Hill AD, Davis ER, Buck BR (2004) Optimization of horizontal well-completion design with cased/perforated or slotted liner completions. In: SPE annual technical conference and exhibition, Houston

Furui K, Fuh G, Morita N (2012) Casing- and screen-failure analysis in highly compacting sandstone fields. SPE Drill Complet 27(02):241-252

Gou B, Zeng M, Guo J, Lai J, Liu Z, Ma H, Zhou C, Liu F (2019) Effects of hydrochloric acid on the mechanical and elastic properties of tight dolomite. Am Rock Mech Assoc, Beijing

Jorden J, Jackson AM, Keller SR, Shuchart CE, Alvarez JO, Quigley MS (2011) Pre-perforated liner design and coiled-tubing acidizing of maximum reservoir-contact (MRC) wells offshore Abu Dhabi. In: The SPE/IADC drilling conference and exhibition. Amsterdam, The Netherlands, Society of Petroleum Engineers
Kumar A, Srivastava AK, Kumar R (2010) Design optimization of slotted liner completions in horizontal wells of Mumbai high field. In: SPE asia pacific oil and gas conference and exhibition. Brisbane, Queensland, Australia: SPE Asia Pacific Oil and Gas Conference and Exhibition, 2010, pp 18-20

Liu X, Morita N (2018) Collapse and bending analysis of slotted liners by 3D FEM under various reservoir conditions. In: SPE annual technical conference and exhibition, Dallas, Texas, USA

Liu H, Guo R, Dong J, Liu L, Liu Y, Yi Y (2013) Productivity evaluation and influential factor analysis for Sarvak reservoir in South Azadegan oil field, Iran. Pet Explor Dev 40(5):627-634

Lou Q, Du W, Han XL, Li DF, Zhang GL (2011) Analysis on the influence factors of casing collapse resistance strength. Adv Mater Res 415-417:2121-2125

Manshad AK, Dastgerdi ME, Ali JA, Mafakheri N, Keshavarz A, Iglauer S, Mohammadi AH (2019) Economic and productivity evaluation of different horizontal drilling scenarios: middle East oil fields as case study. J Pet Explor Prod Technol 9:2449-2460

Mantovano L, Grittini S (2016) Development of a numerical tool to assess the structural resistance of pre-perforated liners. In: SPE thermal well integrity and design symposium, Banff, Alberta, Canada, 2016

Naizhen L, Qing-chun G (2018) Subsection optimization method research of slotted screen liner parameters for horizontal wells. IOP Conference Series Earth and Environmental Science 189(2):022075

Santos AR, Silva PP, Vargas EA Jr, Braga AMB (2008) Collapse analysis of screens used in horizontal open hole gravel pack completion. Lafayette, Louisiana, U.S.A. In: SPE international symposium and exhibition on formation damage control

Xie J (2015) Slotted liner design optimization for sand control in SAGD wells. In: SPE thermal well integrity and design symposium, Banff, Alberta, Canada

Zaisheng L, Jieshan X, Jun C (2001) Application of slotted screen completion technology in Tarim Oilfield. West-china Explorat Eng 69(2):42-43

Publisher's Note Springer Nature remains neutral with regard to jurisdictional claims in published maps and institutional affiliations. 